\title{
PERANCANGAN DAN IMPLEMENTASI USER INTERFACE APLIKASI REKARUANG PADA MODUL KONSULTASI MENGGUNAKAN METODOLOGI WATERFALL
}

\author{
G N Kresna Adiputra ${ }^{1}$, Putra Fajar Alam², Ekky Novriza Alam ${ }^{3}$ \\ ${ }^{1,2,3} \mathrm{~S} 1$ Sistem Informasi, Telkom University \\ Email: ${ }^{1}$ ngurahkresna@ student.telkomuniversity.ac.id, ${ }^{2}$ putrafajaralam@telkomuniversity.ac.id, \\ 3ekkynovrizaalam@telkomuniversity.ac.id
}

\begin{abstract}
The role of interior design is not just room decoration but as a liaison between humans and their environment. In 2017, the interior design business increased by $50 \%$, so the interior design business has an excellent opportunity for now. Based on the results of interviews, some problems still occur behind the increasing development of interior design, especially in the design sales process. The researcher conducts this research to form a solution that addresses interior design problemsby analyzing and designing UI and UX and implementing interfaces using the Vue.Js front-end framework. This research focuses on the Design and Implementation of the Design and Implementation of the Design User Interface for the Web-Based Consulting Module Using the Waterfall Methodology. The design of the Rekaruang application uses a design thinking methodology that produces a design that is tested using usability testing before being implemented in code form. The test results use the SUS calculation method, which makes a score of 86 for the client application design, and 79 for the designer side application design so that the design can be declared acceptable by prospective users of the Rekaruang application. Implementing the Rekaruang application interface in code form uses the waterfall model methodology, which produces a web-based Engineering application. The results of the implementation were tested using a white-box testing technique with the unit testing method. The test results align with the expected expectations because as many as twenty-one test cases tested resulted in successful test status.
\end{abstract}

Keyword:Interior designer, Rekaruang, UI/UX, design thinking, waterfall model, usability testing, unit testing.

\begin{abstract}
Abstrak:Perandesain interior bukan sekedar dekorasi ruangan melainkan sebagai penghubung antara manusia dengan lingkungannya. Tahun 2017 bisnis pada bidang desain interior meningkat sebesar 50\%, sehingga bisnis desain interior memiliki peluang yang baik untuk saat ini. Berdasarkan hasil wawancara, dibalik perkembangan desain interior yang meningkat masih terdapat beberapa permasalahan yang terjadi khususnya dalam proses penjualan desain. Penelitian ini dilakukan untuk membentuk solusi terhadap permasalahan pada bidang desain interiordengan melakukan analisis dan perancangan UI dan UX serta implementasi interfacemenggunakan frameworkfront-end Vue.Js.Penelitian ini berfokus pada Perancangan dan Implementasi User Interface Aplikasi Rekaruang Pada modul Konsultasi Berbasis Web Menggunakan Metodologi Waterfall. Perancangan desain aplikasi Rekaruang menggunakan metodologi design thinkingyangmenghasilkan rancangan desain yang diuji menggunakan usability testing sebelum diimplementasikan ke dalam bentuk kode. Hasil Pengujian menggunakan metode perhitungan SUS yang menghasilkan score 86untuk desain aplikasi client, dan 79 untuk desain aplikasi sisi desainer, sehingga dapat dinyatakan desain diterima (acceptable) oleh calon pengguna aplikasi Rekaruang. Implementasi interface aplikasi Rekaruang dalam bentuk kode menggunakan metodologi waterfall model yang menghasilkan aplikasi Rekaruang berbasis web. Hasil implementasi diuji menggunakan teknik pengujian white-box testing dengan metode unit testing. Hasil pengujian sesuai dengan ekspektasi yang diharapkan karena sebanyak dua puluh satu test case yang diuji menghasilkan status pengujian sukses.
\end{abstract}

Kata kunci:desain interior, UI/UX, design thinking, waterfall model, usability testing, unit testing. 


\section{PENDAHULUAN}

Desain interior adalah sebuah ilmu yang sangat dekat dan kompleks dengan kebutuhan kehidupan manusia(Thamrin, 2017). Berdasarkan hasil wawancara terhadap lima orang desainer interior, pengguna desainer interior didominasi oleh pasangan yang baru menikah dan pemilik usaha. Pandangan dari pemilik usaha berdasarkan proses wawancara yang dilakukan, mereka membutuhkan jasa desainer interior karena menganggap penggunaan jasa desainer interior merupakan sebuah investasi. Dilihat dari kebiasaan calon konsumen saat ini membutuhkan tempat yang Instagram-able, sehingga membuat para pengusaha berlomba untuk memiliki tata ruang yang indah dengan fungsionalitas yang tinggi untuk menarik pelanggan dan meningkatkan kenyamanan maupun kinerja dari pegawainya.

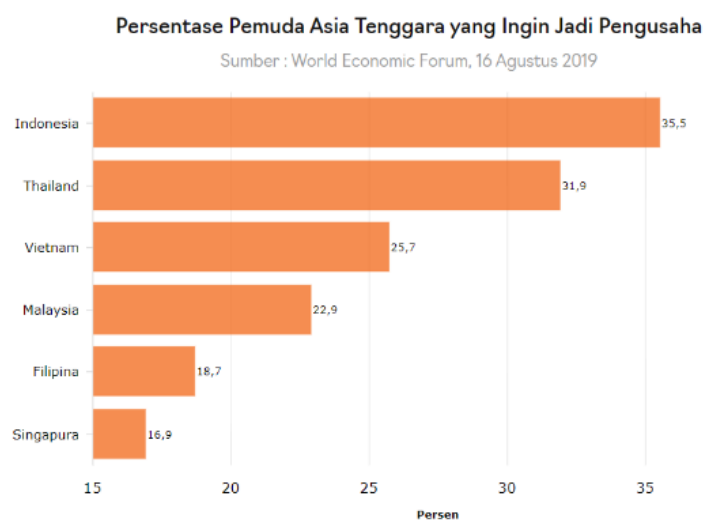

\section{Gambar 1 Data Persentase Pemuda Asia Tenggara Yang Ingin Jadi Pengusaha(Databoks, 2019)}

\section{Menurut World Economic Forum} persentase pemuda Indonesia yang memiliki ketertarikan sebagai pengusaha yaitu sebesar $35,5 \%$ angka yang cukup tinggi dibandingkan dengan beberapa negara di Asia tenggara lainnya seperti yang telah digambarkan pada

Gambar 1. Berdasarkan hal tersebut secara tidak langsung akan berdampak pada tingkat penggunaan desain interior di Indonesia. Hal tersebut berbanding lurus dengan laju pertumbuhan PDB sub sector desainer interior pada tahun 2016 meningkat sebanyak 5,92\% dibandingkan dengan tahun sebelumnya di tahun 2015.
Dibalik tingginya tingkat perkembangan dan peluang bisnis desain interior, berdasarkan hasil wawancara terhadap lima desainer interior dan lima pengguna jasa desainer interior masih terdapat banyak permasalahan yang terjadi. Permasalahan tersebut dialami oleh desainer interior maupun client atau pengguna jasa desainer interior. Sudah cukup banyak perusahaan dan startup yang bergerak pada bisnis desain interior, properti dan arsitek.

Berdasarkan hasil analisis kompetitor masih terdapat beberapa kekurangan, oleh karena itu penelitian ini bertujuan untuk membentuk sebuah platform baru dengan nama Rekaruang yang berfokus pada pembentukan fitur berdasarkan kebutuhan pengguna. Penelitian ini akan membahas cara merancang fitur yang mempertimbangkan aspek UI/UX dan hanya mengimplementasikan salah satu fitur utama berdasarkan rancangan fitur yang terbentuk pada penelitian ini.

\section{METODE}

Penelitian ini menggunakan model konseptual design science research dari Hevver, karena sistem informasi merupakan salah satu disiplin ilmu yang mencakup ilmu tentang perangkat keras (hardware), perangkat lunak (software), dan antarmuka pengguna (human interface) yang beradaptasi secara inheren, sehingga model konseptual dengan pendekatan design science researchsangat relevan dengan penelitian sistem informasi(Laumer \& Eckhardt, 2012).

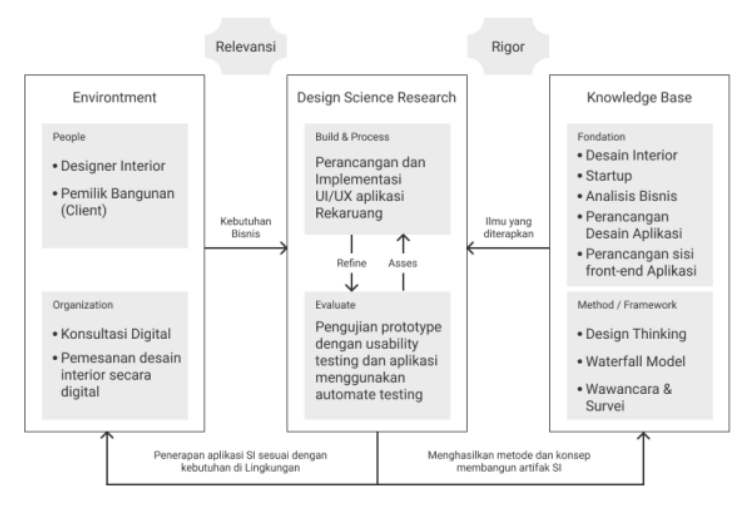

Gambar 2 Model Konseptual

Metode penelitian pada penelitian ini menggunakan waterfallmodelyang terbagi menjadi beberapa tahapan antara lain 
requirement, design, implementation, verification(Elamin \& Daleel, 2016).

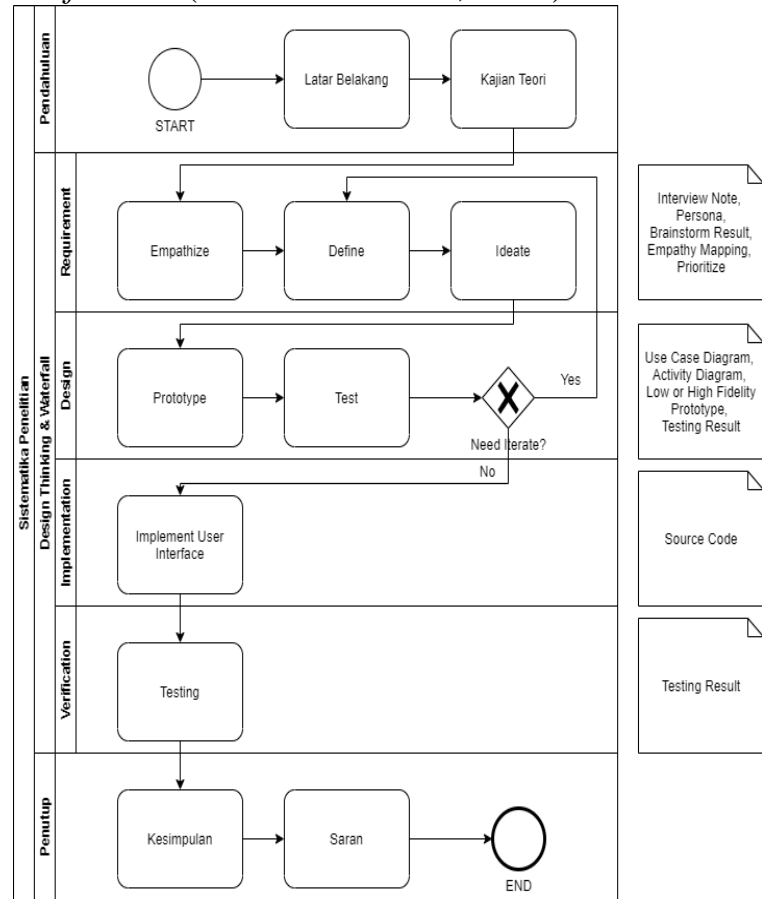

Gambar 3 Sistematika Penelitian

Fase requirement merupakan tahapan untuk mengumpulkan kebutuhan yang dapat di analisis sehingga peneliti dapat mendefinisikan kebutuhan aplikasi Rekaruang. Untuk mendapatkan hasil yang efektif pada fase requirement, peneliti menggunakan tahap empathize, define, dan ideate pada metodologi design thinking.

Fase design merupakan tahapan untuk menghasilkan sebuah rancangan sistem aplikasi Rekaruang berdasarkan hasil dari analisis yang dilakukan pada fase sebelumnya. Peran design thinking pada fase design dapat memberikan tahapan yang efektif dalam merancang sebuah rancangan sistem aplikasi. Pada fase design tahapan design thinking yang dilakukan yaitu tahap prototyping dan testing.

Tahap implementation merupakan tahapan dalam proses implementasi prototype yang dibentuk pada fase sebelumnya yang dituangkan menjadi sebuah source code.

Tahap verification merupakan tahapan dalam melakukan testing aplikasi yang sudah terbentuk pada fase implementation. Testing yang dilakukan pada tahap ini yaitu menguji aplikasi dan mendapatkan bug yang dapat dievaluasi pada bagian-bagian kecil pada aplikasi Rekaruang saat diakses.

\section{HASIL DAN PEMBAHASAN}

Analisis bisnis yang akan dilakukan pada penelitian ini antara lain analisis model bisnis. Analisis bisnis dilakukan untuk memastikan bisnis yang akan dikembangkan telah memenuhi kebutuhan dan kelayakan nilai bisnis yang jelas.

Analisis bisnis menggunakan lean canvas yang memiliki beberapa blok yang perlu dianalisis. Berikut merupakan penjabaran hasil analisis masing-masingblok pada lean canvas.

Customer Segment pada startup Rekaruang antara lain client dan designer interior. Client merupakan pemilik bangunan yang menggunakan jasa desainer interior sedangkan desainer interior merupakan praktisi yang memenuhi kebutuhan client. Early Adopter merupakan pengguna yang memiliki peluang yang besar untuk menggunakan aplikasi Rekaruang yaitu orang yang baru mapan atau menikah dan desainer interior yang ingin mendapatkan penghasilan tambahan.

Problem merupakan permasalahan utama yang dialami pengguna jasa desainer interior saat ini. Berdasarkan hasil wawancara yang dilakukan permasalahan yang dialami oleh client yaitu terdapat kekhawatiran terhadap rancangan desain interior tidak sesuai dengan ekspektasi karena keterbatasan informasi mengenai portofolio desainer interior, Selain itu client belum menemukan penjualan desain interior yang langsung terhubung dengan desainer interior. Sedangkan permasalahan utama yang dialami desainer interior yaitu kesulitan untuk mendapatkan client secara berkala karena kurangnya kesadaran masyarakat terhadap pentingnya penerapan desain interior. Selain itu desainer interior sulit untuk mendapatkan penghasilan tambahan pada bidang desain interior selain dari kantor tempat desainer interior bekerja.

Revenue Stream merupakan sumber pendapatan berdasarkan hasil penjualan produk atau jasa. Revenue Stream pada aplikasi Rekaruang antara lain layanan utama dari aplikasi Rekaruang yaitu pesan desain.

Solution merupakan sebuah solusi yang memungkinkan dalam mengatasi permasalahan. Solution yang ditawarkan oleh Rekaruang antara lain menyediakan informasi portfolio desainer interior yang sesuai dengan kebutuhan dan keinginan client. 
$\begin{array}{ccc}\text { Unique } & \text { Value } & \text { Proposition yaitu } \\ \text { dimiliki } & \text { oleh }\end{array}$ keunggulan yang dimiliki oleh
startupRekaruang yang dapat menjadi sebuah pesan yang disampaikan ke pengguna agar tertarik menggunakan layanan Rekaruang. Unique Value Proposition yang dimiliki oleh Rekaruang antara lain menjual desain interior secara online tanpa perlu bertemu secara langsung namun Rekaruang tidak membatasi jika client ingin bertemu dengan desainer interior. Selain itu Rekaruang juga memberikan kebebasan client dalam memilih desainer interior yang sesuai dengan kebutuhannya untuk memesan desain interior, dan unique value propositionclient dapat berkonsultasi secara real-time dengan desainer interior melalui fitur konsultasi. High Level Concept yang dapat diajukan yaitu kombinasi dari Halodoc dan Fiverr pada bidang desain interior.

Channel merupakan media yang dapat digunakan pengguna untuk menemukan perusahaan Rekaruang. Channel yang dimiliki oleh Rekaruang antara lain social media, website, komunitas, dan konsultan desain interior.

Key metrics merupakan target minimum yang ingin dipenuhi dengan Rekaruang. Key Metric yang ditetapkan pada Rekaruang yaitu memperoleh 20 desainer interior yang terdaftar pada aplikasi Rekaruang dan minimal terdapat 15 desainer yang menjual desain secara online dalam satu tahun, sehingga dapat diasumsikan Rekaruang mampu menjual 351 desain interior secara online dalam satu tahun.

Cost Structure merupakan pengeluaran yang dibutuhkan untuk mendukung proses bisnis pada Rekaruang. Cost Structure yang dimiliki Rekaruang dapat dikategorikan menjadi 3 antara lain: biaya pengembangan aplikasi, biaya pemasaran, dan biaya utilitas.

Unfair advantage merupakan keunggulan yang sulit untuk ditiru oleh kompetitor lainnya. Unfair Advantage yang dimiliki oleh Rekaruang antara lain terdapat desainer interior yang telah di validasi komitmen dan kompetensinya sehingga desainer yang terdaftar pada Rekaruang tersaring dari oknum yang tidak bertanggung jawab, Rekaruang juga bekerja sama dengan perusahaan di bidang arsitektur salah satunya PT Reka Massa ArchitectBali yang telah bekerja sama dengan komunitas HDII Bali.
Selanjutnya analisis dan perancangan desain aplikasi akan dilakukan sesuai dengan sistematika penelitian yaitu menggunakan design thinkingmemiliki 5 tahapan antara lain empathize, define, ideate, prototype dan test(Collina et al., 2018). Tahap yang melakukan analisis atau problem-space pada desain thinking yaitu empathize, define dan ideate sedangkan prototype dan test termasuk ke dalam proses implementasi atau solutionspace (Machado \& Grilo, 2020).

Pada tahap empathize peneliti telah melakukan brainstorming dan mempersiapkan interview note sebagai daftar pertanyaan yang harus terjawab. Pertanyaan dirancang dengan model open-ended question dengan tujuan untuk memperoleh temuan (insight) yang lebih dalam.

Pada penelitian ini peneliti melakukan wawancara terhadap lima orang desainer interior dan lima orang yang berpeluang untuk menggunakan jasa desainer interior. Hasil dari wawancara terhadap lima orang client dapat disimpulkan bahwa persona calon pengguna aplikasi Rekaruang yaitu orang yang berusia sekitar 25 tahun yang familier menggunakan platform digital. Client memiliki kekhawatiran menggunakan jasa desain interior karena harga yang tidak sesuai dengan anggaran yang disetujui di awal selain itu juga client cenderung sulit untuk mempercayai desainer interior karena tidak mengetahui latar belakang desainer. Hal yang diperhatikan oleh client dalam memilih desainer yaitu portofolio, komunikasi, serta kemampuan desainer dalam memberikan layanan berupa konsultasi dan pemesanan konsep desain.

Hasil wawancara terhadap desainer interior dapat disimpulkan bahwa persona desainer interior calon pengguna aplikasi Rekaruang berprofesi sebagai freelancer dan professionaldesigner.Desainer interior terbiasa untuk kerja seacara individu maupun berkelompok tergantung pada besar suatu proyek.Kebutuhan desainer interior yaitu ingin memiliki pendapatan tambahan diwaktu luang, wadah untuk mempublikasikan portofolio yang memiliki pasar. Sedangkan permasalahan yang dialami oleh desainer interior antara lain tidak mendapatkan client secara berkala.

Pada tahap define peneliti merancang persona yang dapat menggambarkan profil calon pengguna aplikasi dan permasalahan yang mereka alami berdasarkan hasil 
Available online at http://jurnal.goretanpena.com/index.php/JSSR

wawancara yang sebelumnya dilakukan pada tahap empathize.

Tabel 1 Persona Client (Pemilik Proyek)

\begin{tabular}{|c|c|}
\hline \multicolumn{2}{|c|}{ Persona Client } \\
\hline \multicolumn{2}{|c|}{$\begin{array}{c}\text { Leslie Alexander } \\
\text { Client (Pemilik Proyek) } \\
25 \text { Tahun }\end{array}$} \\
\hline Demographics & $\begin{array}{l}\text { Leslie merupakan seorang } \\
\text { yang berprofesi sebagai } \\
\text { pegawai swasta dan } \\
\text { memiliki usaha pribadi } \\
\text { yang berkeinginan untuk } \\
\text { menggunakan jasa } \\
\text { desainer interior. Leslie } \\
\text { memiliki kepribadian yang } \\
\text { extrovert, } \\
\text { pekerjaannya dalam } \\
\text { membutuhkan pemikiran } \\
\text { secara analitik dan } \\
\text { terstruktur, memiliki } \\
\text { jadwal yang cukup sibuk. }\end{array}$ \\
\hline $\begin{array}{l}\text { Behavior } \quad \& \\
\text { Activity }\end{array}$ & $\begin{array}{l}\text { - Kualitas, harga, } \\
\text { lokasi dan adanya after } \\
\text { service merupakan hal } \\
\text { prioritas yang digunakan } \\
\text { untuk } \\
\text { mempertimbangkan } \\
\text { produk. } \\
\text { - Menemukan } \\
\text { informasi desainer } \\
\text { interior secara online } \\
\text { maupun offline. }\end{array}$ \\
\hline Goals & $\begin{array}{l}\text { - Mendapatkan } \\
\text { desain dari desainer } \\
\text { interior yang hemat } \\
\text { terhadap waktu. }\end{array}$ \\
\hline $\begin{array}{l}\text { Problem / Pain } \\
\text { Point }\end{array}$ & $\begin{array}{l}\text { - Khawatir } \\
\text { mendapatkan } \\
\text { rekomendasi desain yang } \\
\text { mengecewakan karena } \\
\text { tidak sesuai dengan } \\
\text { ekspektasi. }\end{array}$ \\
\hline Needs & $\begin{array}{l}\text { - Rekomendasi } \\
\text { desain sesuai dengan } \\
\text { yang dibutuhkan. } \\
\text { - Mendapatkan } \\
\text { after service ketika } \\
\text { menggunakan jasa desain } \\
\text { interior. } \\
\text { - Mendapatkan }\end{array}$ \\
\hline
\end{tabular}

\begin{tabular}{|l|l|}
\hline \multicolumn{2}{|c|}{ Persona Client } \\
\hline & $\begin{array}{l}\text { informasi portfolio } \\
\text { desainer yang lengkap. }\end{array}$ \\
\hline Tech Savviness & $\begin{array}{l}\bullet \text { Advanced User } \\
\text { dalam penggunaan sosial } \\
\text { media dan e-commerce. }\end{array}$ \\
\hline
\end{tabular}

Selain itu pada iterasi kedua peneliti membentuk empathy map.Empathy Mapdipisahkan menjadi 4 kuadran, Kuadran pertama yaitu says berisi ucapan yang ditekankan oleh partisipan. Kuadran selanjutnya yaitu think yang berisi insight yang terkait tentang apa yang dipikirkan partisipan. Kuadran selanjutnya yaitu does yang berisi tentang apa saja yang dilakukan partisipan saat berinteraksi dengan sistem. Berikut merupakan contoh empathy map yang telah dibentuk peneliti pada Error! Reference source not found.

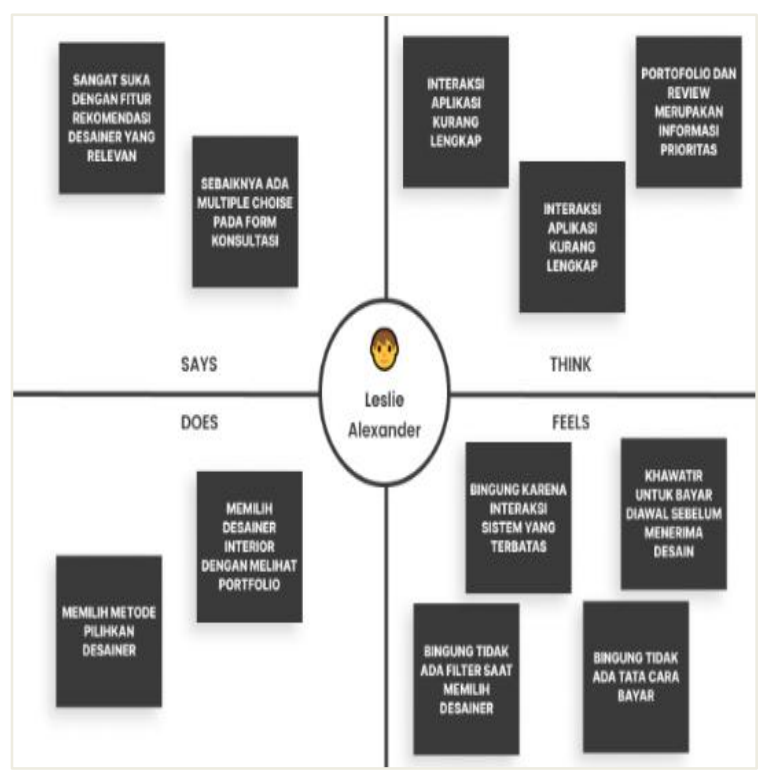

Gambar 4 Empathy Map Client

Pada tahapIdeatepeneliti akan menjabarkan permasalahan pengguna, kebutuhan pengguna, asumsi solusi yang dapat direkomendasikan, dan aspek yang terkait dengan permasalahan pengguna. Pada iterasi pertama peneliti berfokus untuk memberikan rancangan solusi dan ide yang ditujukan untuk menyelesaikan permasalahan pengguna. Pada iterasi kedua peneliti melakukan brainstorming dengan menggunakan metode How Might We (HMW) Question. Berikut merupakan salah satu penerapan HMW Statement. 
Available online at http://jurnal.goretanpena.com/index.php/JSSR

Tabel 2 How Might We Statement Client

\begin{tabular}{|l|l|}
\hline \multicolumn{2}{|l|}{ HMW ke-1 } \\
\hline Permasalahan & $\begin{array}{l}\text { Partisipan tidak yakin } \\
\text { perbedaan dari metode } \\
\text { pada layanan. }\end{array}$ \\
& $\begin{array}{l}\text { Partisipan } \\
\text { membutuhkan } \\
\text { petunjuk untuk } \\
\text { menjelaskan perbedaan } \\
\text { metode layanan }\end{array}$ \\
\hline $\begin{array}{l}\text { Bagaimana } \\
\text { mungkin kita.. }\end{array}$ & $\begin{array}{l}\text { Memberi petunjuk dan } \\
\text { meyakinkan partisipan } \\
\text { untuk memudahkan dalam } \\
\text { memahami perbedaan } \\
\text { metode pada layanan } \\
\text { konsultasi? }\end{array}$ \\
\hline Solusi & $\begin{array}{l}\text { Menambahkan deskripsi di bawah } \\
\text { setiap judul layanan } \\
\text { berupaoverline text. }\end{array}$ \\
\hline
\end{tabular}

Peneliti juga membentuk matriks prioritas untuk memetakan solusi yang paling penting maupun solusi yang bersifat opsional hingga sulit untuk diterapkan.

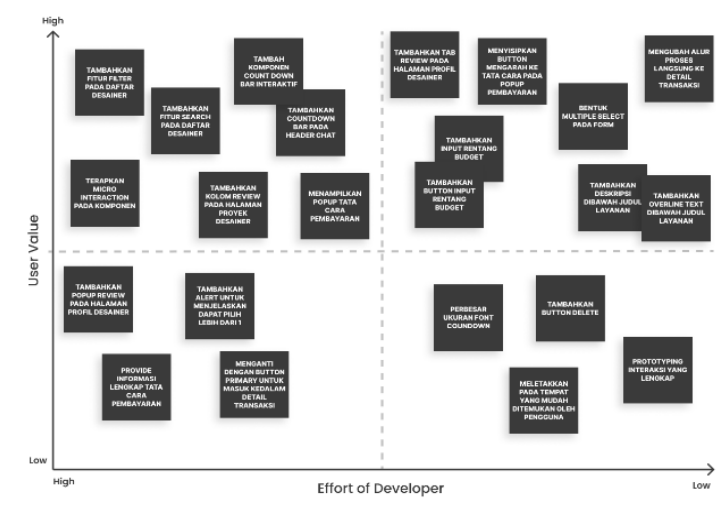

Gambar 5 Prioritize Mapping Client

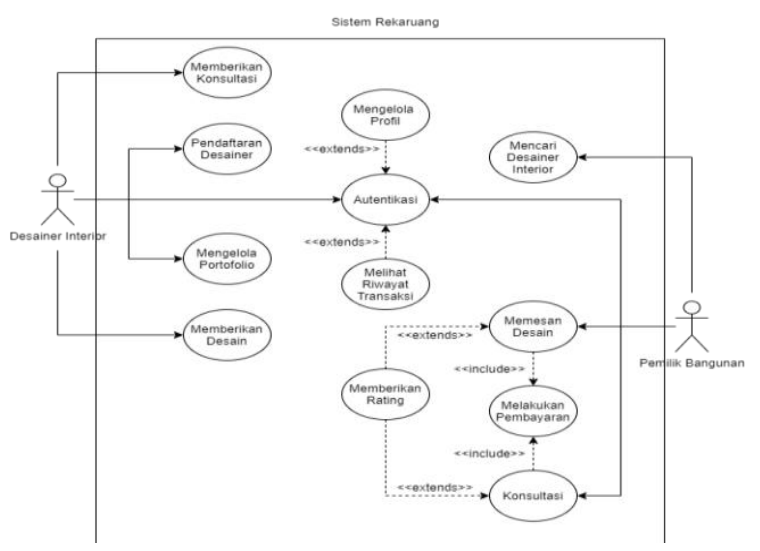

Gambar 6 Use Case Diagram Rekaruang
Pada tahap prototype peneliti juga membentuk UML salah satunya adalahUse case diagram.Use case diagram yang dibentuk akan merepresentasikan minimum viable product sistem Rekaruang yang akan dikembangkan oleh peneliti. Terdapat dua aktor pada sistem Rekaruang antara lain pemilik bangunan (client) dan desainer interior yang memiliki batasan dalam penggunaan fitur - fitur yang dimiliki oleh sistem Rekaruang.Pada Gambar 6merupakan use case diagram yang merepresentasikan minimum viable productpada sistem Rekaruang.Activity diagram juga dibentuk disesuaikan dengan use case yang dimiliki oleh sistem Rekaruang.

Pada tahap prototype iterasi pertama peneliti membentuk desain rapid prototype atau prototype low-fidelity yang berfokus pada alur penggunaan aplikasi dan peletakan atau layout. Pada iterasi kedua peneliti membentuk high-fidelityprototypedan design guideline. Berikut merupakan salah satu contoh penerapan low-fidelity dan highfidelityprototype.

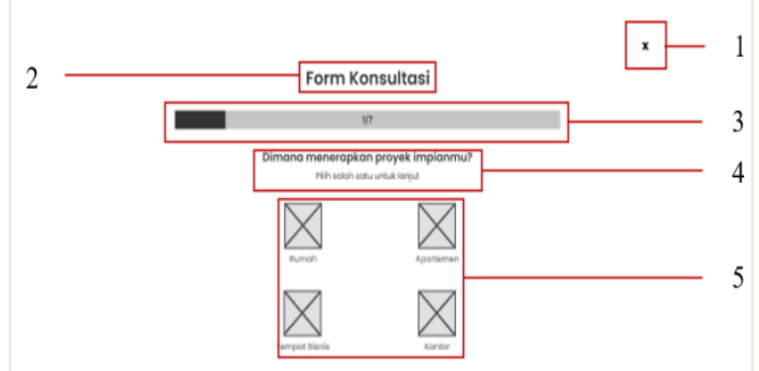

\section{Gambar 7 Low-Fidelity Prototype}

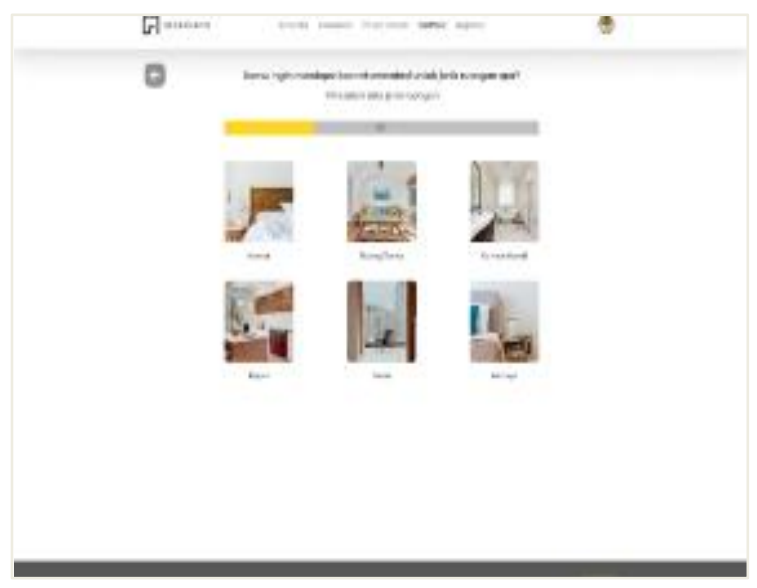

Gambar 8 High-Fidelity Prototype 
Pada tahap test iterasi pertama peneliti menggunakan pengujianusability testing dengan pendekatan kualitatif. Pendekatan kualitatif dilaksanakan untuk mencapai tujuan peneliti dalam mendapatkan masukkan secara mendalam dari partisipan testing terhadap rancangan desain yang telah dibentuk pada tahap prototype sebelumnya.

pada iterasi ke dua peneliti menggunakan usability testing dengan pendekatan kuantitatif. Pendekatan kuantitatifdilaksanakan untuk mencapai tujuan peneliti dalam mendapatkan penilaiandari partisipan. Metode yang digunakan untuk mengukur tingkat kemudahan atauusability pada penelitian ini yaituSystem Usability Scale(SUS).Dari hasil perhitungan SUS, dapat disimpulkan bahwa rancangan desain aplikasi Rekaruang bagian client memperoleh score system usabilityscale86 dan bagian desainer memperoleh score 79sehingga dapat dinyatakan desain aplikasi memilikinilaiadjective Excellentyang berarti rancangan desain produk aplikasi sangat baik dan rancangan desain termasuk ke dalam kategori Acceptable.

Untuk melakukan implementasi rancangan desain aplikasi ke dalam bentuk kode, peneliti menggunakan metodologi pengembangan perangkat lunak atau software development life cycle (SDLC)waterfall model. Melalui Analisis Perancangan Desain yang menggunakan metodologi design thinking tahap requirementdan designtelah dilakukan sepenuhnya(Alahmari \& Anandhavalli, 2018). Oleh karena itu implementasi dan pengujian akan dimulai dari tahap implementation yang dimiliki oleh waterfall model.

Tahap implementation merupakan tahap untuk menerapkan prototype atau rancangan aplikasi yang sebelumnya telah terbentuk dengan menerjemahkan mockup aplikasi Rekaruang ke dalam bentuk kode. Sesuai dengan batasan penelitian ini, penerapan desain aplikasi menggunakan framework Vue.jsyang mendukung aplikasi web dengan pendekatan single page application (SPA) dengan bahasa pemrograman java script dan tidak mencakup pembentukan back-end aplikasi dalam proses implementasi. Pada penelitian ini berfokus pada pembentukan fitur konsultasi pada aplikasi Rekaruang.

Tahap verification merupakan tahap untuk menguji aplikasi. Pengujian aplikasi dilakukan dengan menggunakan cara automatedunit testing menggunakan tools JEST. Hasil pengujian telah sesuai dengan harapan peneliti karena sebanyak 21 test case yang diuji menghasilkan status pengujian sukses atau sudah terpenuhi dan sesuai dengan ekspektasi yang diharapkan.

\section{SIMPULAN}

Pembentukan user interface dengan mempertimbangkan user experience menggunakan metodologi design thinkingmemiliki lima tahap antara lain empathy, define, ideate, prototype dan test. Pada tahap empathy, define dan ideate merupakan tahap peneliti untuk mengumpulkan kebutuhan pengguna dan memberikan rancangan ide-ide asumsi solusi yang mengatasi permasalahan desainer interior dan pemilik bangunan (client). Selanjutnya pada tahap prototype peneliti membentuk interface berdasarkan kebutuhan pengguna sehingga menghasilkan sebuah fitur dan interface yang didasari dengan kebutuhan pengguna. Tahap yang terakhir yaitu test peneliti melakukan validasi terhadap rancangan ide solusi yang ditawarkan untuk memastikan desain aplikasi valid untuk mengatasi permasalahan desainer interior dan client. Dengan menggunakan design thinking Rekaruang menghasilkan fitur - fitur yang sesuai dengan kebutuhan pengguna, sehingga aplikasi Rekaruang berpotensi akan digunakan oleh desainer interior dan client untuk memudahkan pengguna mencapai tujuan.

Proses implementasi interfaceaplikasi Rekaruang menggunakan metodologi waterfall modelyang memiliki empat fase yaitu requirement, design, implementation dan verification.Pada penelitian ini faserequirement dan designtelah terpenuhi pada saat perancangan interfaceaplikasi Rekaruang menggunakan metodologi design thinking. Sehingga untuk proses implementasi rancangan desain aplikasi dimulai dari fase implementationpada metodologi waterfall model. Pada penelitian ini peneliti membentuk interfaceaplikasi Rekaruang menggunakan frameworkVue.Js dengan pendekatan metode pengembangan SPA. Selanjutnya fase yang terakhir pada waterfall modelyaitu verification, padatahap ini peneliti menguji aplikasi Rekaruang menggunakan unit testing yang bertujuan untuk mencari bugpada aplikasi 
Rekaruang. Proses implementasi pada penelitian ini tidak terjadi perubahan kebutuhan pengguna dalam skala yang besar sehingga dapat disimpulkan kombinasi metodologi design thinking dan waterfall membantu memastikan proses identifikasi kebutuhan pengguna dengan lebih baik. Pembentukan menggunakan frameworkvue.js menghasilkan implementasi kode yang lebih terstruktur, ketika startupRekaruang membutuhkan penambahan developer untuk mengembangkan produk Rekaruang akan memudahkan bagi developer baruuntuk memahami dan mengembangkan aplikasi Rekaruang.

Pengujian rancangan prototypeaplikasi Rekaruang menggunakan dua jenis usability testing yaitu kualitatif dan kuantitatif. Pengujian menggunakan usability testingjenis kualitatif memberikan evaluasi secara mendalam terhadap rancangan desain yang dibentuk. Sedangkan pengujian dengan jenis kuantitatif memberikan hasil validasi terhadap kesesuaian rancangan desain yang berhasil dibentuk dengan kebutuhan pengguna. Perhitungan pada pengujian kuantitatif

\section{DAFTAR PUSTAKA}

Alahmari, F., \& Anandhavalli, M. (2018). Using Design Thinking in Information System Development: A Survey. 21st Saudi Computer Society National Computer Conference, NCC 2018, 1-6.

Collina, L., Sabatino, P. Di, Galluzzo, L., Mastrantoni, C., \& Mazzocchi, M. (2018). A Systematic Literature Review for Human-Computer Interaction and Design Thinking Process Integration Chapter (Vol. 10918, Issue June). Springer International Publishing.

Databoks, K. (2019). Persentase Pemuda Asia Tenggara yang Ingin Jadi Pengusaha.

Elamin, M., \& Daleel, E. (2016). Software menggunakan pengukuran SUS yang menghasilkan score 86 untuk rancangan desain aplikasi Rekaruang bagian clientdan 79 untuk bagian desainer interior. Sehingga dapat dinyatakan rancangan desain dapat diterima (acceptable) oleh pengguna. Dengan rancangan desain yang dapat diterima dengan baik oleh pengguna maka akan meningkatkan potensi pengguna untuk menggunakan aplikasi Rekaruang.

Pengujian hasil implementasi front-end aplikasi Rekaruang menggunakan teknik pengujian white-box testing dengan metode unit testing. Pada penelitian ini hasil pengujian telah sesuai dengan harapan peneliti karena sebanyak 21 test case yang diuji menghasilkan status pengujian sukses atau sudah terpenuhi dan sesuai dengan ekspektasi yang diharapkan. Maka, dapat disimpulkan bahwa setiap unit kode yang dihasilkan dapat berjalan dengan baik. Sehingga ketika aplikasi Rekaruang sudah dirilis dan digunakan oleh pengguna, aplikasi Rekaruang akan lebih stabil, dapat dipercaya dan diandalkan untuk menjalankan proses bisnis yang dimiliki Rekaruang.

Engineering Development and Analysis of Life Cycle Models. International Journal of Computer Applications, 133(10), 9-13.

Laumer, S., \& Eckhardt, A. (2012). Integrated Series in Information Systems Volume 28. In Springer (Vol. 28).

Machado, F., \& Grilo, A. (2020). How can design thinking and lean startup improve waste collection systems? Proceedings of the International Conference on Industrial Engineering and Operations Management, August.

Thamrin, D. (2017). Memahami Interior Sebagai Penghubung Abstrak. October. 